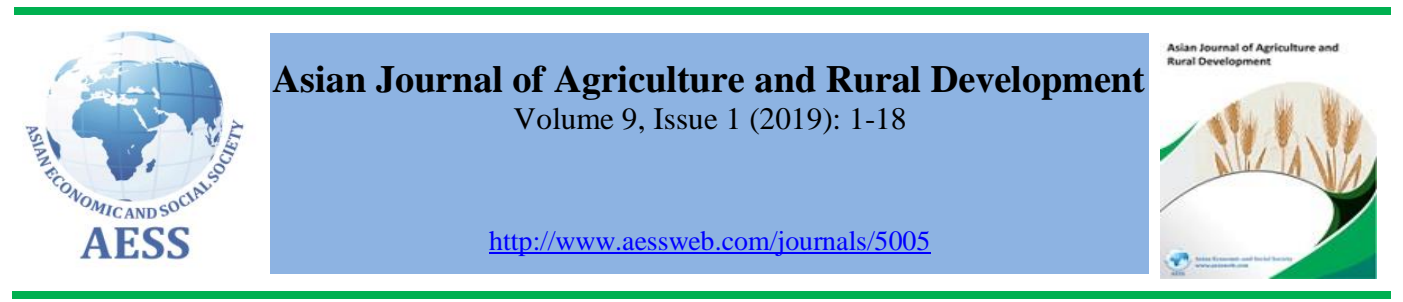

\title{
A REVIEW OF EGYPTIAN AFFORESTATION PROGRAM AND ITS EFFECT ON AGRICULTURE
}

\author{
a Department of Agrotechnology, Faculty of Sciences \\ M. Subandi a and Technology. The State Islamic University of Sunan \\ Abdelwahab M. \\ Mahmoud $^{b}$ \\ Gunung Djati of Bandung, Indonesia \\ Cecep, T. $^{\mathrm{c}}$ \\ b Department of Plant Physiology, Faculty of Agriculture, \\ Cairo University, Egypt \\ c PhD Candidate; Cairo University, Egypt and Staff of \\ Indonesian Embassy of Cairo, Egypt \\ $\bowtie$ mhd.subandi@uinsgd.ac.id (Corresponding author)
}

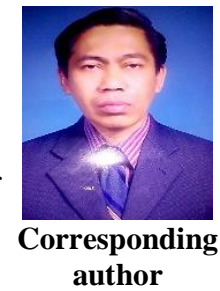

\section{ARTICLE HISTORY:}

Received: 22-Aug-2018

Accepted: 18-Jan-2019

Online Available: $12-\mathrm{Feb}-$ 2019

\section{Keywords:}

Afforestation,

Agricultural,

Gunungkidul,

The Nile,

Wanagama

\begin{abstract}
Egypt has been famous as agricultural country since ancient times. Most Egyptian horticultural and food crop plants are shrubs or small trees with shallow root systems. These plants are susceptible to drought and have a little or no hydrological effect. Egyptian agriculture is mostly dependent on the Nile water $(82.59 \%)$. Desert areas can be ecologically reclaimed or restored to agronomically productive areas if socioeconomic, cultural, and political factors permit the restoration. Afforestation is when a desert is turned into a woods or forest as a climate change agent and water reservoir. This survey found that Egyptian land was greener than Indonesian land. The availability of the Nile water should be managed as effective as possible to accelerate Egyptian afforestation projects. Egypt may imitate Indonesian success in re-greening the Gunungkidul region of Jogyakarta with the Wanagama forest. The afforestation program affects agricultural practices in Egypt in both the near- and long-term.
\end{abstract}

\section{Contribution/ Originality}

The current study shed light on the agricultural system of Egypt and discuss the linkage between agriculture and running afforestation programs by concerned authorities. Further, this study compares the land quality of Egypt with other countries, such as Indonesia.

DOI: 10.18488/journal.1005/2019.9.1/1005.1.1.18

ISSN (P): 2304-1455/ISSN (E):2224-4433

How to cite: M. Subandi, Abdelwahab M. Mahmoud and Cecep T. (2019). A review of Egyptian afforestation program and its effect on agriculture. Asian Journal of Agriculture and Rural Development, 9(1), 1-18.

(C) 2019 Asian Economic and Social Society. All rights reserved. 


\section{INTRODUCTION}

Egypt is famous as a country of having long and high civilized culture since the era of ancient Egypt, and it evident are apparent from artifacts found and mentioned in the Holy Qur'an. And indeed big and populous city of Cairo indicating that Egypt has been inexistence among the oldest and civilized countries in the world. Egyptian land is predominant barren desert, but the Nile River makes the country prosperous and really beautiful as Figure 1.

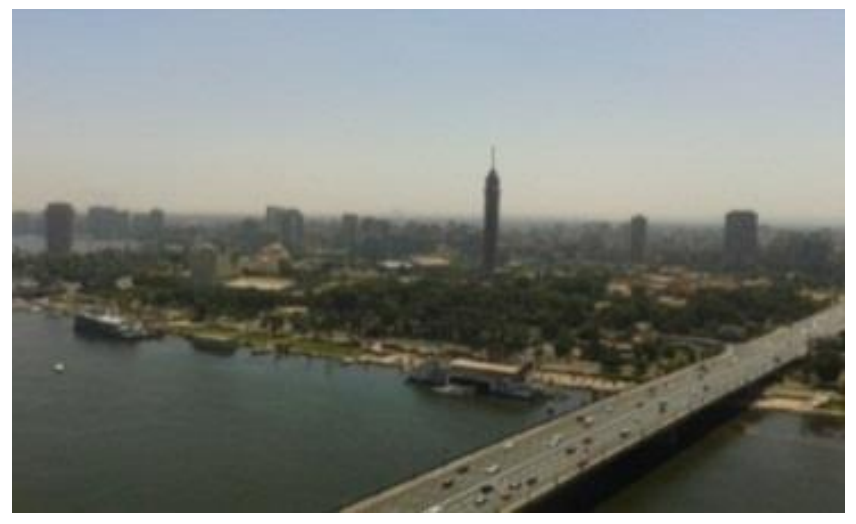

\section{Figure 1: Rich and big city of cairo passed by the Nile river}

Woody plants growing well (as shown in Figure 2), is showing that land in this country is arable. Geographic and climatic data show Egyptian land is mostly desert and with its very low rainfall. This natural condition may sometimes be associated with poor and backward country, but not for Egypt. So, why is Egypt prosperous and belonged to developing or developed country? Seeing the demographic and natural sources, the answer is because Egypt is passed and controls the Nile water with its continuous considerable debit supplying irrigation water for agricultural practices.

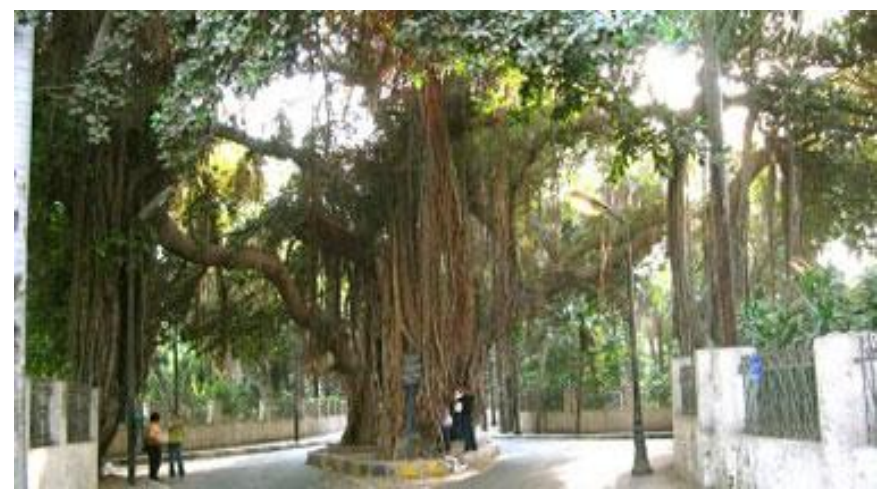

Figure 2: Woody plants species grow well in Cairo

Egypt region is mostly desert, and arid or semi-arid range lands and Egypt considers as one of the oldest agricultural territories; the River Nile allowed a sedentary agricultural society to develop thousands of years ago (El-Nahrawy, 2011).

Desert was formed only recently compared to the formation of the earth. It is the result of integrated and simultaneous happening of natural processes and human deeds. Degradation of land quality due to natural or geologic process, water eroded and wind winnowed the top soil. Finest clay and silt were firstly blown by wind and eroded by water. No conservation measures of uneducated or better 
said irresponsible people or governments or administration made the cultivated land neglected and degraded (Maya, 2011; Chalise et al., 2019).

Soil erosion, loss of productivity potential and biodiversity, soil \& water pollution and water shortage are ongoing processes that decrease/ degrade provisioning (e.g., biomass, freshwater) and regulating (e.g., carbon sequestration, soil quality) and ecosystem services (Zalesny et al., 2016).

The cause of the non-existence of forest in Egypt is not only due to the climatic conditions and the scarcity of rainfalls, but also as a result of the urbanization and the focus on food production for meeting the consumption of rapid increasing population (Hany, 2014). Historical notes and facts give us reasons to blame the bad conduct of people and mismanagement in ancient eras to the nature. So desertification is process of natural that was accelerated by human

This understanding is firmed basic for human to regain the good condition of land as it was, and Egypt is agricultural country, and it has been famous since the era of Prophet Joseph. Out of the agricultural product, Egypt produces horticultural crops and food crops. Most of horticultural and food crop plants are shrubs or a small trees with shallow root system. And these families of plants are susceptible to drought and have a little or no hydro-orology effect. In soil and water conservation view point these plants are classified as bad vegetation.

Horticulture and food crop products are of most important as food supply and they generate wealthy to the farmers, and so the crops are also named as cash crops. However the plants are vulnerable to water supply problem due to shallow root system, and the land planted with these crops is also vulnerable to erosion due intensive and frequent and intensive soil tillage.

Sound land-use policy should equalize areas for agricultural production and land for being planted with trees (vegetation) for supporting conservation of soil and water. More over existence of vegetation (woods or forest) in catchment areas will be the reservoir and control water supply to ditches and rivers and influence regional climate. So that, afforestation program is a must, and it is possible in Egypt as the Nile water is available.

There is natural competition among the varieties of plants as stated that planted forests had negative effects on the diversity of native desert shrubs and trees. Using flood irrigation and large space between trees might help in conserving the floristic diversity of desert shrubs and trees at the forest floor (Emad and Linderholm, 2012).

Vegetation growing in Egyptian Desert and found there were 4 vegetation groups, two may symbolise the vegetation types of the Western Mediterranean coast of Egypt, and two other groups may represent the Wadi Hagul (El-Amier et al., 2015).

There are habitual or characteristic of Egyptian tribes' life as described by reporting that pastoral nomads from the Hadandawa, Amar Ar, Bishaari, Ababda and $\mathrm{Ma}^{\mathrm{c}}$ aza tribes in the Red Sea hills of Egypt and Sudan have relied on drought persistent Acacia tortilis trees for millennia. And presently, political, social and economic factors impose changes in traditional livelihoods and land use. A variety of local pruning practices, previously considered destructive by many outsiders, conform to good practice described in modern literature (Gidske et al., 2014).

The resistance of soils to degradation processes by human positive actions is known as soil resilience. Soil resilience has been defined as the capacity of a soil to recover its functional and structural integrity after a disturbance. Abdel and Ali (2012) noted in Egypt the main land degradation types in irrigated agriculture are salinization and alkalization as the effects of high rate of transpiration of the Nile water. 


\section{METHODOLOGY}

Literature review and on site survey on re-greening of Egyptian desert lands have been conducted. Afforestation programs planned were reviewed through observation and literatures study. On the site observation was conducted to get empirical and the views of academicians. Interviews with academicians of Cairo University and the Suez Canal University were conducted.

For comparison, results of on the spot survey and literature study on the re-greening or reforestation of the barren Gunungkidul for three decades. A region in Western part of Jogyakarta, a Sultanate Special Region, and Central Java, Indonesia was presented. This fact of Indonesian success in regreening its barren area has been the initiate idea for this review of Egyptian afforestation.

\section{AFFORESTATION PROGRAMS}

Proudly Egyptian academician acknowledged that Egyptian land was greener than Indonesian. It is proven with some artifacts which are maintained in Cairo University, Geology laboratory. One of the facts is some cuts of wood in form of semi-fossil. Counted some thousands years ago the current semi-fossil was fresh wood growing in the present sterile dry sandy lands (desert). It must be fertile and humid and green land formed of Egyptian a long time ago, but natural destruction and accelerated by human mismanagement acts had made the land and barren desert.

Dillinger (2017) noted that around 70,000 hectares of Egyptian land is forested. Between 1990 and 2000, Egypt gained an average of 1500 hectares per year, but the rate of forestation has since decreased by $2.71 \%$ per year. The percentage of land covered in forest in Egypt is not likely to change in the near future, due to wooded areas being lost to urbanization and windblown sands.

Egypt has also such the program as this shown in the Figures 3 below. The program of afforestation of a desert is very difficult and requires patient to maintain, and costly. However this program is for the life of people of a nation in the future. It requires much sacrifices and great struggles. All people of nation and government have to pay high intention for the success.

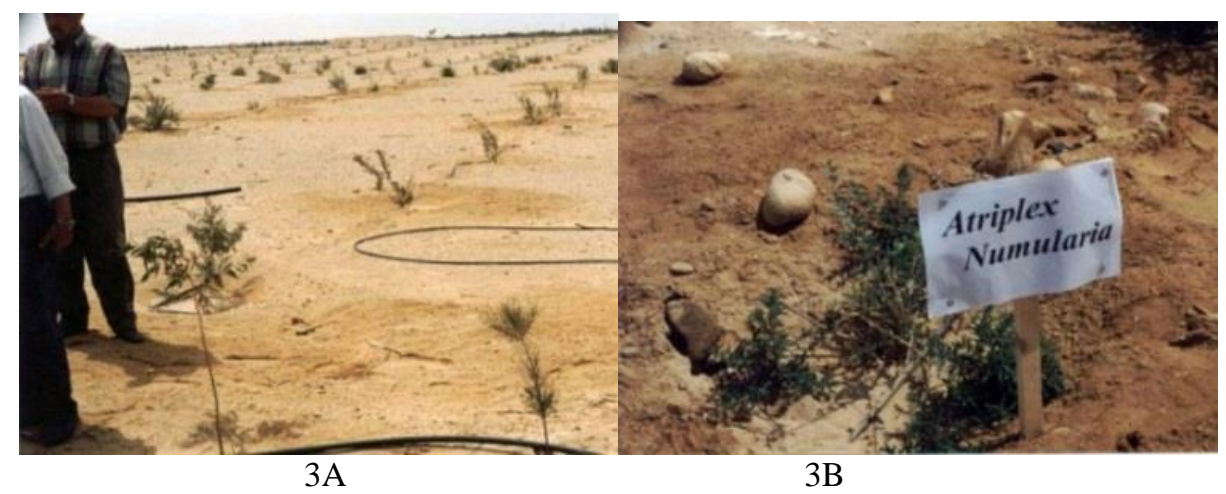

Figure 3A and 3B: Vegetative method in Egypt: transplanting fodder trees and shrubs: an efficient way to control desertification and for use as a source of feed (Source: El-Nahrawy, 2011)

Other studies and researches conducted in relation to re-green desert of Egypt. Among other was a study made by Monier (1998) indicated that silt, clay, moisture content, organic carbon and calcium carbonate were the main abiotic environmental variables correlated with species distribution in the study area. A total of 141 plant species belonging to 32 different families were recorded in this study, mostly of Sahara-Arabian distribution, with xerophytes followed by chamaephytes dominating the life-form spectra. High species richness was recorded in vegetation of sand plains, moist muddy flats 
and runnels, contrasting with salinized and limestone plains. Soil texture, organic carbon and moisture content are correlated with species diversity in the richer habitats, while high salinity and calcium carbonate are the main factors associated with lower species diversity. And Sayed et al. (2013) found physiological adjustments to enhance tolerance or avoidance of drought were studied in three desert plants growing in WadiNatash (Eastern Desert). Studied plants are (Zillaspinosa (L.), Citrulluscolocynthis (L.), Schrad and Morettiaphilaeana (Dalile) DC.). The results suggest that osmotic adjustment was the main water relationship adaptation to cope with drought.

El-Ghani et al. (2011) described around Egyptian desert is still found some climbers. In some genera, all of the species are climbers (e.g. Serjania). High abundance of climbers is an important physiognomic feature differentiating tropical from temperate forests. Figure 4 shows some woody plants of afforestation in Egypt.

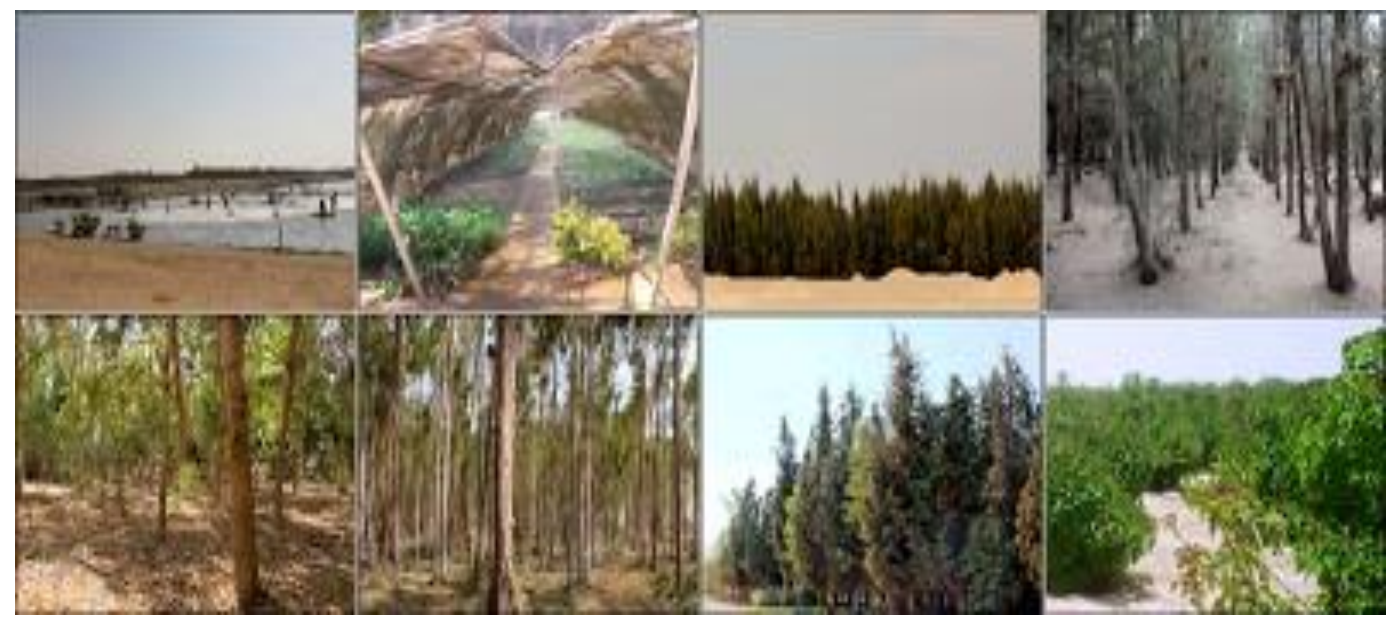

Figure 4: Upper photos from right: sewage water basin; tree nursery; afforestation in desert land; and casuarina plantation. Lower: khay a trees; eucalyptus; Cupressus; Jatropa plantation

Hany (2014) reported problem in Egypt is the greatest challenges facing Egypt are aside from health, education, poverty and "corruption", Egypt is facing many challenges. 1. Arid/desert climate; 2. Water scarcity; 3.Misuse of the limited fertile land to secure food for the increasing population; 4. High susceptibility to climate change: 5 . Absence of innovative, environmentally-friendly solutions, and: 6. Mismanagement of resources. He further stated according to the Executive Secretariat of the United Nations Convention to Combat Desertification, Egypt lost $9 \%$ of its arable lands to constructions over the past 36 years. The country is ranked first in the rate of desertification with a loss rate of 3.5 acres per hour (35 ha or 50 soccer fields daily) of fertile Delta agricultural land, which is an incomparable rate in the world statistics.

In case of climate change effect, Egypt is ranked 3rd in rising sea levels after all low-lying Island States and Vietnam (World Bank, 2009).

The authors and public can see there are many big woody trees and vegetation grow well in around of city of Cairo. Why Egyptian did not plant the perennial trees outside Cairo regions? By starting planting at the easily irrigated regions in both banks of the Nile. At these regions irrigation water may easily be managed. Re-greening the banks of Nile by a good and sustainable and planned program to initiate the change of desert ecology. It may last for decades or for centuries, and Egyptian people and governments must keep the program for generations as long as the Pharaoh dynasty had made Egyptian land barren. Based on reliable information (the Noble Qur'an), Pharaoh 
Dynasty had made many destructions in the country and had made not any conservation except had made big buildings.

It is reported, and there are records refer to the fact that the highest rate of forest tree-cutting in Egypt took place during the Ayobeed Era (where more than 12,000 trees were cut down in a rather short time span, of which 9,500 in Qualiobeya governorate alone) (Hany et al., 2014). This proves that forest eradication was done by man and not due to the climatic or environmental factors. Sinai peninsula was very rich in its forest cover, and this is justified by the numerous names given to the dry valleys scattered on this desert. Names indicating the places or regions of rich in water.

When the re-greening program is executed, gradual but sure, this region will be growing green with the perennial plants (big trees with deep root system), and this type of plant will grow and develop for tens of years changing the micro-climate then the regional climate improved. The statement of geologist (a professor), and the Head of Geology Laboratory of Cairo University that Egyptian land was greener than Indonesian land in the last time is very logic. It might be in the time of Pharaoh Dynasty. And the natural condition will be regained, of course, with hard willing of political and considerable national funding, and of brilliant of academician and field leaders.

Possibility for Egypt to re-green her lands is guaranteed with the huge supply of water of the Nile. Urban area of Cairo with more than 10 million of population producing wastewater treated or untreated are potential for being organic manure for plants accelerating growth. Hany (2014) saw it as opportunity and calculated sewage water about 7 billion m3annually, of which approximately $40 \%$ is only treated and 5.5 billion m3sewage water for the afforestation and assuming an average annual water requirement of $8,500 \mathrm{~m} 3 / \mathrm{ha}$ and 650 thousand ha in the desert lands can be afforested (nearly $20 \%$ of the total agriculture area). And25 million tons of CO2annuallycan be stored.

Hany et al. (2014) made detailed approach to establishment of large-scale plantation forests in the desert lands of Egypt, and mapped the area to be planted as the Figure 5. The approaches are:

1. Making optimal use of the potential available in the wastewater and in plantation forests.

2. Building of forest administration liable to implement the forestry policy, to provide guidelines for forest management, to approve and to control the implementation of forest management plans.

3. Capacity building of trainers and technical staff.

4. Enhancing education and research related to wastewater and forest management.

5. Complement with researches to accompany the afforestation activities.

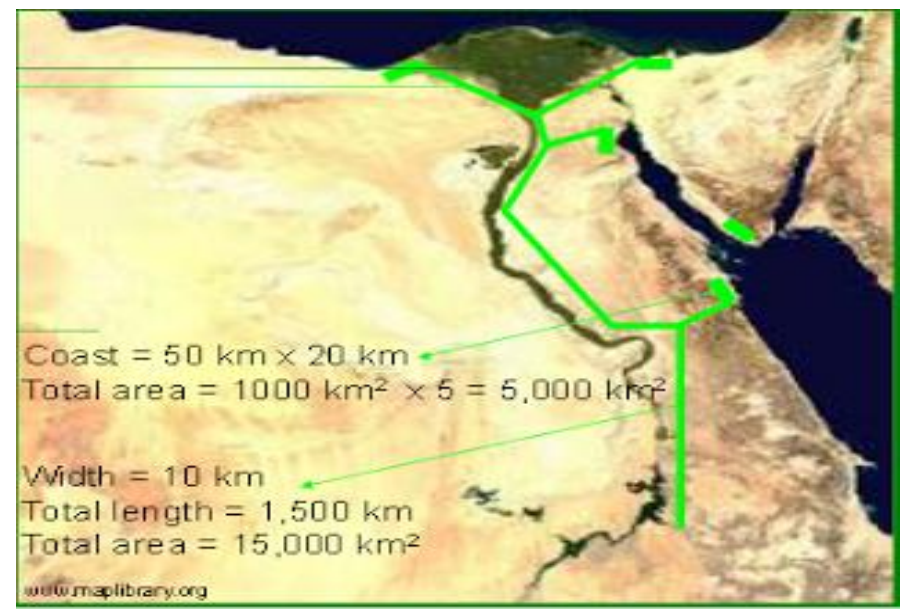

Figure 5: Map of afforestation in Egypt Hany et al. (2014) 
Analyzing the map prepared by team of Hany with collaboration of Germany concentrated the afforestation on the East desert and neglected the West desert and the catchment area of upper Aswan. The Eastern desert is more possible and easier to be re-greened compared to the Western desert. Correction and critics for the Map (prepared by Hany et al of Afforestation, the program concentrated on the Eastern desert and on the one bank only. Another side of banks has to be regreened, too. It will be easier to get water. The Upper zone of the Nile, and the Catchment area of Aswan Dam, must be re-green. Dimension of the area is concentrated on the Nile (for easier irrigation), the width may initiate one or two km only. This policy is to enable distribution area in all Governorates along the Nile.

Some researchers have made calculation in the fields as Fawzy et al. (2016) reported the inland part of the Eastern Desert of Egypt can be divided into four main geomorphological and ecological regions, from the north to the south: 1) the Cairo-Suez Desert, 2) the Limestone Desert, 3) the Sandstone Desert, and 4) the Nubian Desert. The inland part of the Eastern Desert lies between the range of the Red Sea coastal land in the east and the Nile Valley in the west. It is a rocky plateau dissected by a number of wadis. Each wadi has a main channel with numerous tributaries.

And the condition in upper Aswan and the surrounding area was stated by Springuel et al. (2006) as in an extreme desert stream channel (Wadi Aggag near Aswan, Egypt, precipitation $1 \mathrm{~mm}$ per year), vegetation structure and soil water content were investigated over a period of 13 years (one downstream site) or parts of this period (two upstream sites). Three large precipitation events were observed in that time $(1987,1990,1996)$. After each storm, densities of 10-15 individual plants per $\mathrm{m} 2$ were produced within a few weeks. This number decreased to almost zero during the following years before the next rain destroyed the surviving individuals. The stands of vegetation that developed subsequently after the floods contained mostly Zillaspinosa, Morettiaphilaeana, Fagoniaindica or Salsola.

Plant growth in the extremely arid southern part of the Eastern Desert of Egypt is supported by the torrential moisture stored in the subsurface layers of wadi-fill deposits. The space-time stratification of the soil moisture and corresponding adaptive stratification of root systems lead to the niche separation of the species. Zillaspinosa, has a low mortality at early and middle life, but a rapid change to high mortality at a later stage (Springuel and Sheded, 1990; Puente, 2011).

It is hard to deal with the Eastern desert natural climate condition for surviving but water give hope and some possibility. This is based on the result of research conducted by Ziada et al. (2016) showed Abu Tartur area is located $600 \mathrm{~km}$ Southwest of Cairo, in Al Wadi El Gadid Governorate, Egypt. Its center lies at $25^{\circ} 25^{\prime}$ North and in $30^{\circ} 02^{\prime}$ East with the top of about 550 masl. Its climate is hot and extremely dry. Recently, the oases have attracted the attention of government authorities as a possible addition to the cultivated area of Egypt. The oases represent unique areas of prosperous land amidst desolate desert. The oases have special ecological conditions and characteristics vegetation. Vegetation of the oases of Western desert of Egypt has been extensively studied by many researchers. Wadi El Natron. No attention has been given to vegetation and ecology of Abu Tartur plateau. The phosphate project of Abu Tarturis considered to be one of the biggest mining projects in the world.

There are many potentials and hope still uncovered in the Western desert, when there is an effort there will be a way out. Egyptian should make a long and hard work for re-greening its land, and may consider the Indonesian experience. A long observation conducted by the authors on Javanese character (people of Yogyakarta Province of Indonesia) revealed that Yogyakarta Special Region which is governed by a Sultan (the current Sultan is Sri Sultan Hamengkubowono X), and Yogyakarta people are obedience to their Sultan. The Sultan is very charismatic, all spoken and written regulations decreed are obeyed by all people. Yogyakarta people's experience in re-greening the Gunungkidul barren land worth noting. Keys success of Gunungkidul re-greening are: 
1. People especially that live in surrounding the region are willingly support. They will be the maintainer as well as the keeper. Forestry Police much easier in their duties if all people involve in keeping the forest.

2. Political will of all level governments. Decentralization of the project is better for they will invite the local government (Governorate administration) to take responsibility.

3. Budget allocation of all level governments (district, province, and national) beside foreign aid.

So the key success for any afforestation is people participation and there is serious political will of the government.

Other policy for the success is selection of vegetation to be planted. Selection or sorting of the plant family or species must be primary based on hydro-orology point of view and not on economic. Hard wood (perennial plant) and deep rooted will much influence to ecology amendment. Below is list of plant species (Hany et al., 2014).

1. Acacia (Acacia nilotica and Acacia saligna), shrub (windbreak)

2. Casuarina (Casuarinaequisetifolia), shrub (windbreak).

3. Jatropha (Jatrophacurcas), shrub (biofuel crop).

4. Jojoba (Simmondsiachinensis), shrub (biofuel crop).

5. Indian beech (Pongamia pinnata), tree (biodiesel).

6. Gmeline or White Teak (Gmelinaarborea), precious hardwood.

7. African Mahogany (Khayasenegalensis), precious hardwood

8. Outeniqua yellowwood (Podocarpusfalcatus), precious hardwood

9. Teak (Tectonagrandis), precious hardwood.

10. Mangium or Black Wattle (Acacia mangium), hardwood.

11. Neem, also Indian Li as lac (Azadirachtaindica), hardwood.

12. Lemon-scented gum (Corymbiacitriodora), hardwood.

13. River Red Gum (Eucalyptus camaldulensis), hardwood.

14. Canary Island pine (Pinuscanariensis C. Smith), softwood.

15. Caribean Pine (Pinuscaribbea var. hondurensis), softwood, and

An afforestation area may be planted with some species this make some advantages as Maiti and Kumari (2016) stated that different woody plants attain different heights, thereby facilitating each species to absorb solar energy without competing with its neighbours, thereby offering amicable landscape on land surface.

Moringaoleifera is now widely cultivated in North Egypt and there are many students register for Master and Ph. D on it (as shown in Figure 6). Moringaoleifera woody plant grow to the height of $8 \mathrm{~m}-12 \mathrm{~m}$. This semi-scrub tree is of economic value and can be planted in multiple-copping system with higher woody plants to get better effect on land and give conservation influences to ecology. Oliveira et al. (1999) stated Moringaoleifera Lam. is a multipurpose tree cultivated to use as a vegetable, for spice, for cooking and cosmetic oil and as a medicinal plant. 


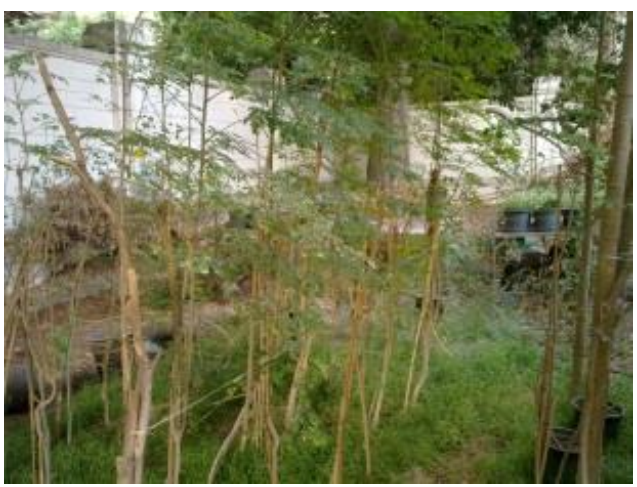

$6 \mathrm{~A}$

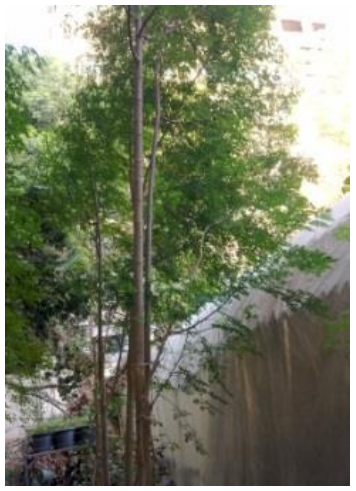

$6 \mathrm{~B}$

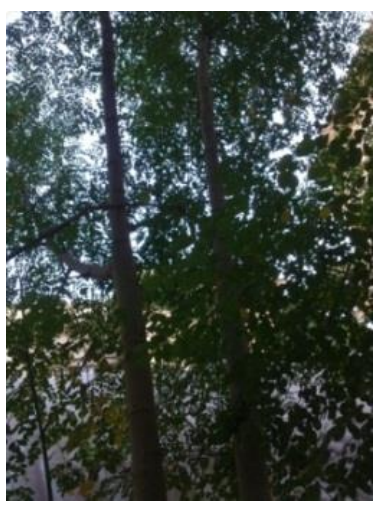

$6 \mathrm{C}$

Figure 6A, 6B \& 6C: Moringa oleifera planted in Seed Bed, and Trees of 3 years old (9 $\mathrm{m}$ high) in Research Garden of Faculty of Agriculture, Cairo University

\section{THE NILE RIVER}

The river Nile is the longest river in the World. The source of the river is in Burundi in Central Africa, it then flows through Sudan, Ethiopia and Egypt and empties into the Mediterranean Sea. Hany et al. (2014) described periods of heavy monsoon rainfall which increase the water level of the Nile causing it to flood in Egypt between June and September. The first Aswan dam was opened in 1902 but it proved to be insufficient and had to be raised twice in 1907-1912 and 1929-1933. The Aswan High Dam which, since its opening in 1970 has prevented further floods. Available and potential water in Egypt is presented in Table 1.

Table 1: Available and potential water resources (in billion $\mathrm{m}^{3}$ on annual basis)

\begin{tabular}{lcccc}
\hline Source & Potential amount & \% & Amount in use & \% \\
\hline Nile water & 55.5 & 75.2 & 51.7 & 82.59 \\
Ground water & 11.3 & 15.3 & 5.2 & 8.3 \\
Re-use of agricultural drainage water & 5 & 6.8 & 3.7 & 5.91 \\
Treated sewage water & 1.5 & 2.03 & 1.5 & 2.4 \\
Rain & 0.5 & 0.67 & 0.5 & 0.8 \\
Total & 73.8 & 100 & 62.6 & 100 \\
\hline
\end{tabular}

Source: Adopted from Abouzeid (1992)

Ancient Egyptian farmers were waiting for flood of the Nile to cultivate crops or to rear fishes. Overflowing water of Nile initiated the farmer activities. People life depended on flood water. Now, the Nile water overflowing on both the River banks has not been more happening, because the current of Nile has been controlled with the Aswan dam. In this era people of Egypt have successfully established Aswan dam. Egyptian farmers cultivate their crop base on the modern agricultural practices. Water of Nile is managed in according to modern irrigation. Subterranean irrigation system is applied to get maximum utilization of water on highly rate of evaporation region. People maintains the Nile river well, Nile water flows in Cairo is better maintained, in view of people hesitates to throw something to the river, and most people build their houses face to the Nile. This is unlike practice in other countries where people arranges their residence and put river in back part of their houses.

Zalesny et al. (2011) reported the Nile River provides nearly 97\% of Egypt's freshwater supply. Egypt's share of Nile waters is fixed at 55.5 billion cubic meters annually. The USAID guidelines for safe and direct reuse of treated wastewater for agricultural purposes were approved in 2005 (Egyptian Code 501/2005). 
In this couple of years was heard the news about the dispute of Nile. Some countries in upper Nile regions claimed to have the right to utilized Nile water. In fact, millions of people in several countries in this region are concerned. Egyptian government was worried about that claim, and was reported to have to send several envoys of ministerial levels to lobby the governments of the claiming countries.

It seemed Egyptian ministers have succeed in handling the Nile crisis. And conflict no more to be worried about. Now people in Egypt no more talking about it. How long this stable condition will guarantee the nation for water supply? The ever-process in this region is the change. A new emerging country in South Sudan, with predicted different political characteristic with Sudan as friendly to Egypt. It is a great challenge for Egypt.

What should be prepared by Egyptian? To deal with that "bad dream". Egyptian land should make woods and forest that keep water and initiate rivers flowing in Egyptian land. Hydrology plants or plants conserving water must be well planted. Afforestation which is now programed by the Ministry of Agriculture and Land Reclamation of Egypt has to be accelerated and doubled or multiplied. And this is possible because water (the Nile water) is available. The forest or woods or plantation will be the natural reservoir and supply water to ditches and rivers as supplement to or substitute of the Nile.

\section{GUNUNGKIDUL OF INDONESIAN REGREENING}

The author interviewed some academicians of Cairo University and Suez Cannel University and referred to Indonesian success in reconditioning the environment and micro-climate in Gunungkidul region of Jogyakarta province. The re-forestation or re-greening program of Gunungkidul region was executed by regional government and supported by all people and the academician (Faculty of Forestry, Gajah Mada University), then the woods is named Wanagama (meaning Woods of GadjahMada University). In the 1964reforestation was begun led by a forestry professor of the university.

At that time Gunungkidul region was famous for scarce water region, de-forestry, barren, rivers were dry in the dry season. And most of its people went out their villages to cities for seeking job (illustrated with Figure 7A and 7B). Faculty of Forestry of Gajah Mada University made the region of 600 ha as field laboratory, and the regional Government of Jogjakarta funded the reforestation programs. The satisfactory result, is shown after 32 years (shown in Figure 8A and 8B), now the region is greenish scenery and almost full of vegetation, and water is easily found here and there. Problem of water in Gunungkidul region is solved by reconditioning the barren area to growing woods. 


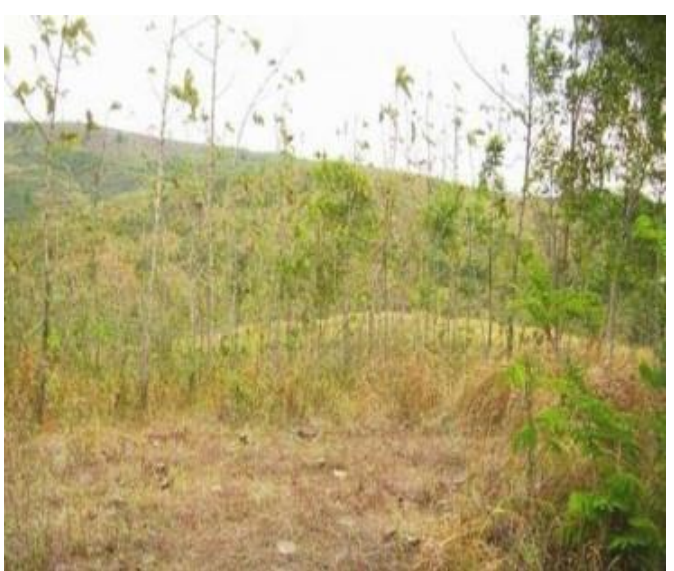

$7 \mathrm{~A}$

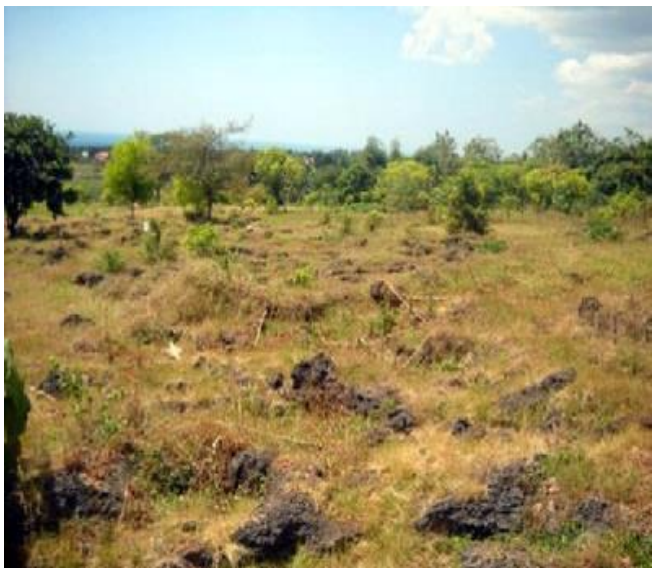

7B

Figures 7A and 7B: Critical and neglacted areas in gunungkidul. jogjakarta, central java, Indonesia

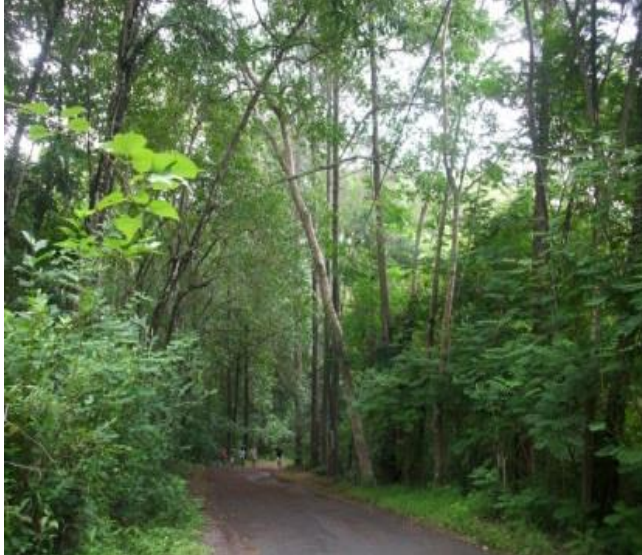

$8 \mathrm{~A}$

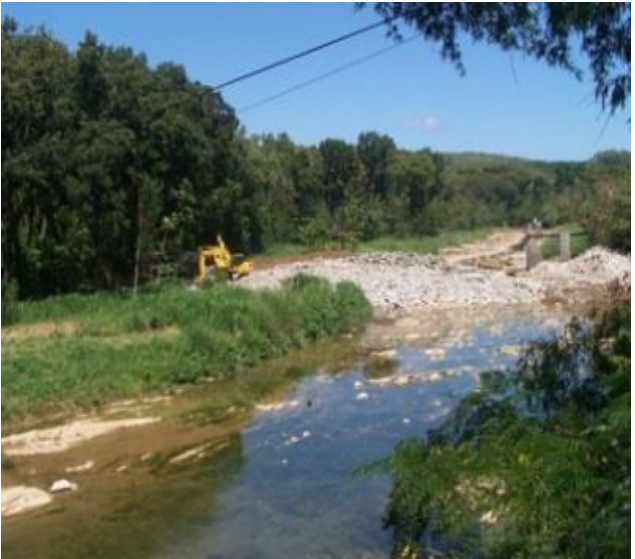

$8 \mathrm{~B}$

Figures 8A and 8B: Present ecology in Wanagama woods of Gunungkidul

Suharno (2008) found that the involvement of multi-stakeholder in the social forestry development comprises national level, provincial government of Yogjakarta Special Territory, regional government of Gunungkidul, Non-Governmental Organization, community, and academic. The changes of social capital due to the involvement of multi stakeholder are mutual trust, network, and social norms. The implements of welfare and forest preservation by the involvement of multi stakeholder are indicated by apparent from the improvement of welfare of the members of the social forestry farmers and cover area of the social forestry area.

Result of interviews and observation on the success of Wanagama woods establishment has been supported by many factors and parties and conditions:

1. Serious and sustainable management of foresters (Faculty of Forestry of Gajah Mada University, and the Regional Administrator/Governor of Jogyakarta (Sultan of Special Region of Jogjakarta)

2. Support of Budget provided by Provincial Government.

3. Participation of the People of Gunungkidul of Jogyakarta (good character of people guided by the throne of Jogjakarta/obedient to the Sultan). People supported and willingly maintained 
any regulations released by the Regional government to keep the woods in Wanagama. It is of prime importance is the participation of the local people and communities, capitalizing on their traditional knowledge and practices. Clear land-use rights are essential to sound land management. Reinforcing people's control over resources and guaranteeing them secure and fair access ensures their long-term commitment to resource conservation

Study conducted by Untung (2003) noted that Wanagama forest generates some advantages for people as:

1. The planting of tress converted degraded and critical land areas into fertile lands.

2. The management of Research and Empowerment of Forest in fact converted the community adjacent to the Forest in particular and in general the people of Gunungkidul Regency from poverty to prosperity.

3. Their prosperity was generated by the products from the trees they planted namely fruits and timbers.

4. The community started practicing agro forestry. They planted a variety of trees, with the main species is teak.

5. The benefit of the Wanagama was conspicuous by the existence of teak forest grown on private lands, especially in Gunungkidul, which produces sizeable amount of timber.

\section{AFFORESTATION ENHANCMENT IN EGYPT}

The main Egyptian public institutions in charge of forestry administration on the national level is the Ministry of Agriculture and Land Reclamation, i.e. Undersecretary of Afforestation. However, on the provincial and local levels the municipalities are responsible for such affairs which are directed by the local authorities of the Governorates. Forestry activities represent 1 (one) \% approximately of the total budget allocated to Ministry of Agriculture and Land Reclamation. The current expenditure and investments are mainly used to establish and maintain nurseries, dealing with afforestation (Mamdouh, 2000). Egypt ratified the United Nation convention to combat Desertification UNCCD in 1995. This convention defined desertification as phenomenon and combating desertification as activities that aimed at:

- Prevention and/ or reduction of land degradation.

- Rehabilitation of partly-degraded lands.

- Reclamation of desertified lands.

The state assigned the responsibility for the implementation of the Convention to the Ministry of Agriculture and Land Reclamation in 2001. Desert Research Center was assigned to be the National Focal Point Coordinator for the Convention. A Ministerial Decree was issued to establish a national coordinating committee chaired by the Minister of Agriculture and Land Reclamation.

Reforestation will make Egypt not dependent on the Nile water only. In the future Egypt should develop and give more attention to establish national forestry. When the forest is established national climate will be influenced and change. Ground water and subterranean water will also develop to substitute the Nile water.

A re-greening program should be planned involving all people and government of Egypt, and of course supported with the budget, and lasting for long, very-very long, may be for centuries. Of course the condition is very different from Gunungkidul of Indonesia. Climatic and ecology are different, but there is advantage in Egypt. Egypt has the Nile, water is always available to guarantee the supply for the need of the newly growing woods. Egyptian people and any ruling governments have to struggle for a longer period, may be twice 30 years or for centuries. 
The Figures 9A and 9 B below show water and possible plant to be grown. There is a big hope, a dense forest will establish in this area with the available water of the Nile. For comparison, water is always available in the bank of the Nile for the year long, but rainfall is only available in rainy season in Gunungkidul of Indonesia. So, we are optimistic woods and forest will develop in this area of the Nile banks. And we believe that in this area, a long time ago, were ever-green woods and dense forest. It is stand to reason academician of Egyptian said "Egyptian land was greener than Indonesian land".

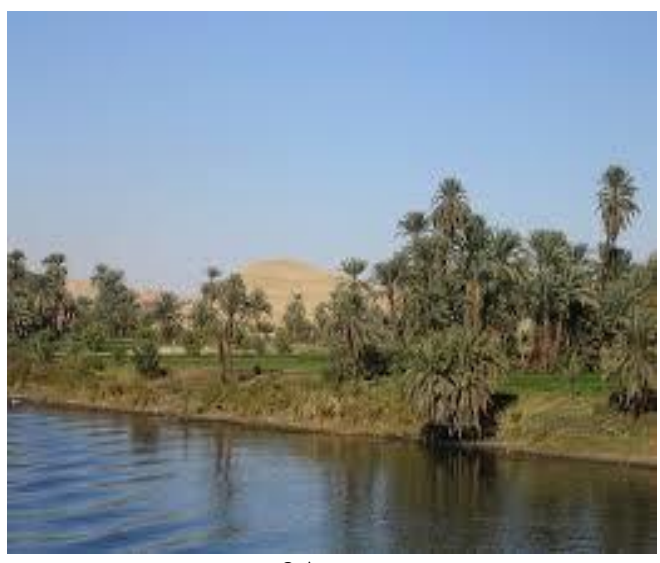

$9 \mathrm{~A}$

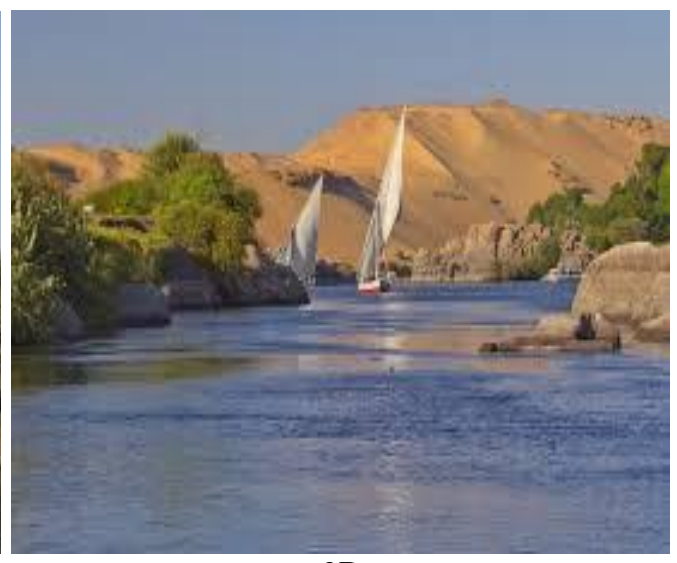

9B

Figures 9A and 9B: The Nile water available is waiting for man-involvement to re-green its banks

In the photos of the Nile banks look green vegetation grow here and there. Evergreen due to water is available all the years long. Unlike the vegetation in Gunungkidul, when lack of water comes and in dry season, vegetation turn wilt. And when the furlong dry season happens and the severe drought cause permanent wilt resulting in devastated species of vegetation. Not enough water and the plants become stressed and eventually die. This will not happen in the bank of the Nile where water is available for a year long. So we are optimistic, there is absolutely possible to develop woods along the Nile banks, and eventually forest established in the region. And regional climate will change, too. Egyptian is obliged to regain this condition, and to get Egypt more welfare and prosperous country as it was in the time of Prophet of Joseph.

There are several steps of works that must be taken to the rehabilitation work, and they should be well managed. The measures in question are: Efforts to improve the condition of the microclimates and the effort for the rocky soil conditions begin:

1. Grow type of plant that allow overgrown flora having shallow roots while trying to enrich the nutrient nitrogen and macro and other micro nutrients.

2. Use, as the first step, plant types that has a deeper root system.

3. Select tree species that grow in accordance with the requirements of the habitat conditions.

It is required very long time, and will need generation to generation to get Egyptian green as it was. It may be realistic and logical as Pharaoh Dynasty had governed Egypt for thousands of years and made the land as barren as it is now. It requires struggles and sacrifices of all people and governments of Egypt for generations. 


\section{SOME EFFECT ON AGRICULTURAL PRACTICES}

Now we know Egyptian government has successfully turned some areas of Western desert to farmlands (shown in Figure 10 A, B, C). Related with this program of re-greening desert of Western part, the NGN (2010) reported with several facts of photos. Bird's-eye view shows the farming village of Abu Minqar in Western desert, remote desert farm village in Egypt. It was reported that this is a success program.

Home to about 4,000 people, the village is an example of Egypt's ambitious and controversial plan to turn its deserts into farmlands though the land is just planted by horticultural subsistence crops. "This is one of the most isolated communities-by distance and by desert-in Egypt," said director of the Desert Development Center of a university in Cairo.

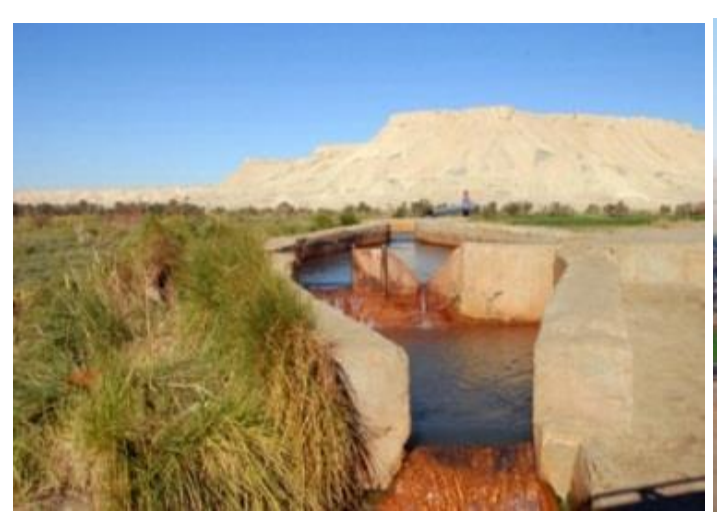

$10 \mathrm{~A}$

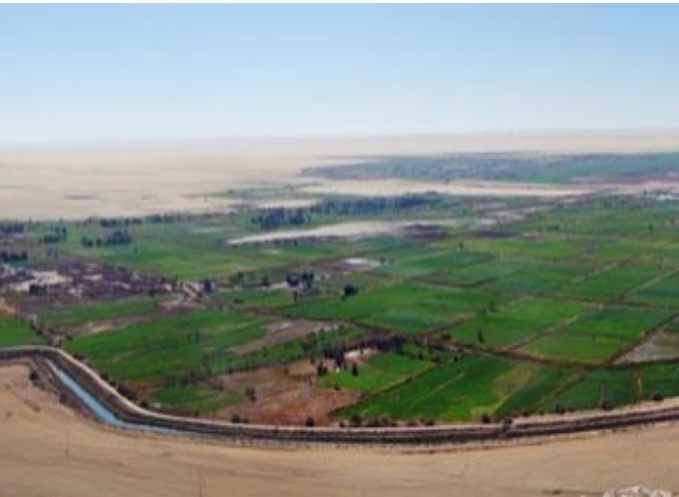

10B

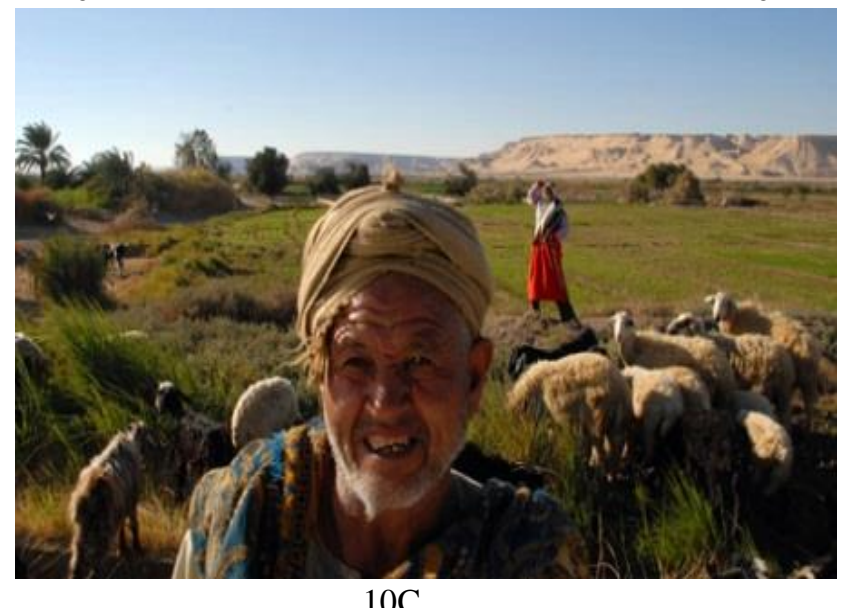

$10 \mathrm{C}$

Figure 10A: Artesian well water feeds cannel; 10B: Farming village of Abu Minqar; 10C: A shepherd tends his sheep (Source: National Geographic News, 2010)

The success of government to turn desert to farmland should not the final goal, because farmland is not giving change to the permanent water resource, even farmland only consume the water and over exploited makes the farmlands back to barren land and desert. Gradually the farmlands must be turned to plantation of tall woody and deep rooted plants.

Tree planting has often been proposed as a way to increase rainfall. It has been estimated that 60 percent of rainfall over the moist evergreen Amazon forest comes from the forest itself through evapotranspiration and the water back through rain (Amazon, 2007). 
Water as source of improving agricultural practices may initiate all life activity of plant and animals (livestock). It means agricultural is to get its core to develop.

Forestation will change regional climate regime, (especially humidity and temperature) and stimulate cloud formation and may result in rainfall that the country urgently needs. This will affect the dynamic cultivation and economic of agricultural activities. Table 2 shows the dynamic of cropping in Egypt. Horticulture crops (vegetable and fruits) showed significant increase, in the year 2008/09 reached $10.6 \%$ for vegetable and $20.6 \%$ for fruits.

Table 2: Changes in area harvested by crop group (in $M$ ha.)

\begin{tabular}{|c|c|c|c|c|c|c|c|c|c|c|c|c|}
\hline \multirow[t]{2}{*}{ Crop group } & \multicolumn{2}{|c|}{$\begin{array}{c}\text { Year } \\
1980 / 84\end{array}$} & \multicolumn{2}{|c|}{$\begin{array}{c}\text { Year } \\
1990 / 91\end{array}$} & \multicolumn{2}{|c|}{$\begin{array}{c}\text { Year } \\
2000 / 01\end{array}$} & \multicolumn{2}{|c|}{$\begin{array}{c}\text { Year } \\
2006 / 07\end{array}$} & \multicolumn{2}{|c|}{$\begin{array}{c}\text { Year } \\
2007 / 08\end{array}$} & \multicolumn{2}{|c|}{$\begin{array}{c}\text { Year } \\
2008 / 09\end{array}$} \\
\hline & area & $\%$ & area & $\%$ & Area & $\%$ & area & $\%$ & area & $\%$ & Area & $\%$ \\
\hline Cereals & 2 & 42.6 & 2.25 & 46.2 & 2.65 & 46.1 & 2.96 & 43.7 & 2.97 & 42.4 & 2.98 & 42.9 \\
\hline Legumes & 0.14 & 2.9 & 0.15 & 3.2 & 0.17 & 3 & 0.12 & 1.8 & 0.11 & 1.6 & 0.13 & 1.9 \\
\hline Fibres & 0.48 & 10.2 & 0.4 & 8.3 & 0.31 & 5.4 & 0.27 & 4 & 0.25 & 3.6 & 0.22 & 3.2 \\
\hline Sugar crops & 0.11 & 2.4 & 0.13 & 2.6 & 0.19 & 3.3 & 0.21 & 3.1 & 0.23 & 3.3 & 0.25 & 3.6 \\
\hline Oil crops & 0.08 & 1.8 & 0.03 & 1.9 & 0.12 & 2.1 & 0.03 & 0.4 & 0.02 & 0.3 & 0.02 & 0.3 \\
\hline Fodder crops & 1.28 & 27.3 & 1.13 & 23.1 & 1.18 & 20.7 & 1.18 & 17.4 & 1.15 & 16.4 & 1.17 & 16.9 \\
\hline Fruit & 0.17 & 3.6 & 0.23 & 4.8 & 0.48 & 8.4 & 1.37 & 20.2 & 1.4 & 20 & 1.43 & 20.6 \\
\hline Vegetables & 0.43 & 9.2 & 0.48 & 9.9 & 0.7 & 11 & 0.63 & 9.4 & 0.87 & 12.4 & 0.74 & 10.6 \\
\hline Total & 4.58 & 100 & 4.81 & 100 & 5.75 & 100 & 6.77 & 100 & 6.37 & 100 & 6.94 & 100 \\
\hline
\end{tabular}

Source: Economic Affairs Department, Agricultural Statistics Bulletin (2009)

\section{CONCLUSION}

Desert was created by nature and by man-mismanagement over exploiting the land. There are afforestation programs in Egypt conducted by the Government, and there are aids of foreign collaboration showing a great participation. Need all out participation of the whole Egyptian and political will of all level government as the success of Indonesian (Jogyakartan) in re-greening the Gunungkidul (Wanagama forest) region. Re-greening or afforestation must be supported and participated by all components of nation, and social and cultural approach are of significant effect. Egyptian agricultural activities were not yet conservation oriented indicating with the species of crops grown. Food crops and horticulture crops are high economic value and cash generator, but lack of or no soil and water conservation effect.

\footnotetext{
Funding: This study received no specific financial support.

Competing Interests: The authors declared that they have no conflict of interests.

Contributors/Acknowledgement: All authors participated equally in designing and estimation of current research.

Views and opinions expressed in this study are the views and opinions of the authors, Asian Journal of Agriculture and Rural Development shall not be responsible or answerable for any loss, damage or liability etc. caused in relation to/arising out of the use of the content.
} 


\section{References}

Abdel, K. W. A. M., \& Ali, R. R. (2012). Assessment of soil degradation and resilience at northeast Nile Delta, Egypt: The impact on soil productivity. The Egyptian Journal of Remote Sensing and Space Science, 15(1), 19-30. doi.org/10.1016/j.ejrs.2012.01.001.

Abouzeid, M. A. (1992). Major issues in Egypt's water resources and irrigation policy: to the next century key note address. Roundtable on Egyptian water policy, in: Proceedings of a seminar on Egyptian water policy, sponsored by the water research center, the ford foundation and winrock international. doi.org/10.1002/ird.331.

Amazon (2007). A Dry Horizon for the Amazon. Climate changes are pushing rain forests to the point of no return. http://scienceline.org/2007/06/ipcc environment_amazon philllips/.

Chalise, D., Kumar, L. and Kristiansen, P. (2019). Land degradation by soil erosion in Nepal: a review. Soil System, 3(12), 1-18. doi:10.3390/soilsystems3010012

Dillinger, J. (2015). The smallest forest in the world. Accessed on 20 May 2016. http://www.worldatlas.com/articles/the-smallest-forests-in-the-world.html.

Economic Affairs Department, Agricultural Statistics Bulletin (2009). Ministry of Agriculture, Cairo, Egypt. Retrieved from http://www.sis.gov.eg/Story/68079?lang=en-us.

El-Amier, Y. A., El-Halawany, E. S. F., Haroun, S. A., \& Mohamud, S. G. (2015). Vegetation analysis and soil characteristics on two species of genus Achillea growing in Egyptian Desert. Journal of Ecology, 5, 420-433. doi.org/10.4236/oje.2015.59035.

El-Ghani, M. A., El-Kheir, M. A., Abdel-Dayem, M., \& El-Hamid, M. A. (2011). Vegetation analysis and soil characteristics of five common desert climbing plants in Egypt. Turkish Journal of Botany, 35(5), 561-580. doi.org/10.1016/j.ejbas.2016.03.001.

El-Nahrawy, M. A. (2011). Country pasture/forage resource profile Egypt. Accessed on 20 May 2016. http://www.fao.org/ag/agp/agpc/doc/counprof/egypt/figures/fig5b.jpg.

Emad, F., \& Linderholm, H. W. (2012). Ecological impacts of desert plantation forests on biodiversity. African Journal of Ecology, 50(3), 308-318. doi.org/10.1111/j.13652028.2012.01325.x.

Fawzy, S., El-Ghani, M. A., Gadallah, M., EL Naggar, S. A. L. A. H., \& Amro, A. (2016). Characteristics of desert vegetation along four transects in the arid environment of southern Egypt. Turkish Journal of Botany, 40(1), 59-73. doi.org/10.3906/bot-1403-108

Gidske, A. L., Krzywinski, K., Talib, M., Saadallah, A. E., Hobbs, J. J., \& Pierce, R. H. (2014). Traditional nomadic tending of trees in the Red Sea Hills. Journal of Arid Environments, 106, 36-44. doi.org/10.1016/j.jaridenv.2014.02.009.

Hany, El K. (2014). Use of the potential of the available resources in Egypt for sustainable Development. Institute of Silviculture Technische Universität München (TUM). elkateb@forst.wzw.tum.de

Hany, El K., El-Gindy, Abdel, G., Bernd, S., Ahmed, A. S., Haifeng, Z., Ahmed, K. M., AbdElwaheb, A., Bernhard, F., Hossam, H., Nashwa, H., Sara, K., Abd-Elbaky, M., Michael, W., El Hakim, M., \& Reinhard, M. (2014). Silvicultural experiment. German-egyptian collaboration to afforestation: forestry in desert lands of Egypt Manual. Edition September 2015. 
Maiti, R., \& Kumari, A. (2016). Innovative techniques and hypotheses developed for plant and crop improvement. Journal of Bio Innovation, 5(2), 270-284.

Mamdouh, R. (2000). Country report, Egypt. FAO. Forestry department. Accessed on 29 July 2016. www.fao.org/docrep/meeting/x4987e.htm.

Maya, Y. (2011). Environmental assessment of eroded soils. Tropical and Subtropical Agroecosystems, 13(2), 169-179.

Monier, M., \& El-Ghani, A. (1998). Environmental correlates of species distribution in arid desert ecosystems of eastern Egypt. Journal of Arid Environments, 38(2), 297-313.

NGN (National Geographic News) (2010). Egypt turns desert into farmland. Accessed on 21 May 2016 http://news.nationalgeographic.com/news/2008/01/photodalleries/Egyptpictures/photo4.html.

Oliveira, J. T. A., Silveira, S. B., Vasconcelos, I. M., Cavada, B. S., \& Moreira, R. A. (1999). Compositional and nutritional attributes of seeds from the multiple purpose tree Moringa oleifera Lamarck. Journal of the Science of Food and Agriculture, 79(6), 815-820. doi.org/10.1002/(sici)1097-0010(19990501)79:6<815::aid-jsfa290>3.3.co;2-g.

Puente, E. O. R., Beltran, F., Ruiz, F., Valdez, R., Garcia, J., Avila, N., Partida, L., \& Murillo, B. (2011). Sustainable options for soil management in arid zones: uses of the halophyte salicornia bigelovii (torr.) and biofertilizers in the modern agriculture. Tropical and Subtropical Agroecosystems, 13(2), 157-167.

Sayed, S. A., Gadallah, M. A., \& Salama, F. M. (2013). Ecophysiological studies on three desert plants growing in Wadi Natash, Eastern Desert, Egypt. Journal of Biology and Earth Sciences, 3(1), 135-143.

Springuel, I., Mohamed, S., Frank, D., \& Reinhard, B. (2006). Vegetation dynamics in an extreme desert wadi under the influence of episodic rainfall. Polish Botanical Studies, 22, 459-472.

Springuel, M. S., \& Abed, W. (1990). Plant growth in relation to a rain incident in WadiAgag, South Egypt. Vegetatio, 90(2), 159-165.

Suharno, A. (2008). The involvement of multi-stakeholder in social forest in gunungkidul regency, Yogyakarta province. Thesis of Master Degree of Post Graduate Program Hasanuddin Universitas of Makasar.

Untung, I. (2003). The impact of managing a research and education forest in Indonesia. Paper submitted to the XII World Forestry Congress 2003, Quebec City, Canada. Accessed 20 May 2016. http://www.fao.org/docrep/ARTICLE/WFC/XII/0102-C1.HTM\#fn1.

World Bank (2009). Convenient Solutions to an Inconvenient Truth: Ecosystem-based approaches to climate change. Washington: The World Bank.

Zalesny, Jr, R. S., Stanturf, J. A., Evett, S. R., Kandil, N. F., \& Soriano, C. (2011). Opportunities for woody crop production using treated wastewater in Egypt. I. Afforestation strategies. International Journal of Phytoremediation, 13(1), 102-121. doi.org/10.1080/15226514.2011.568539.

Zalesny, R. S., Stanturf, J. A., Gardiner, E. S., Bañuelos, G. S., Hallett, R. A., Hass, A., Stange, C. M., Perdue, J. H., Young, T. M., Coyle, D. R., \& Headlee, W. L. (2016). Environmental technologies of woody crop production systems. Bio Energy Research, 9(2), pp.492-506. doi.org/10.1007/s12155-016-9738-y. 
Ziada, A. M. E., Al-Shamy, M. M. A., \& Jalal, M. J. (2016). Ecological study on vegetation of Abu Tartur plateau, the new valley, Egypt. Journal of Environmental Science and Technology, 9, 88-99. doi.org/10.3923/jest.2016.88.99. 